\title{
Surgical treatment of post-transplant encapsulating peritoneal sclerosis: A single-center experience
}

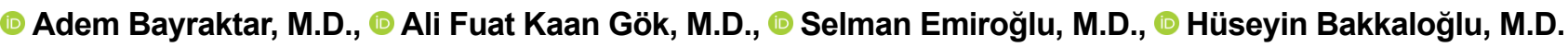

Department of General Surgery, İstanbul University İstanbul Faculty of Medicine, İstanbul-Turkey

\begin{abstract}
BACKGROUND: Encapsulating peritoneal sclerosis (EPS) related to peritoneal dialysis (PD) has a vague etiology and high mortality. In this study, our aim was to determine treatment options for EPS cases.

METHODS: A total of 169 patients underwent kidney transplantation from January 2008 to January 2018 and II9 patients from a cadaveric and 50 patients from a living donor. Twenty-one patients were undergoing PD before the transplantation. The mean PD time was 6.9 (IQR 3-I4) years. Four patients received surgical treatment for EPS that occurred after the transplant. After the surgical treatment, 2 patients died because of sepsis. Two patients were discharged without complications, but I had late-term EPS recurrence.

RESULTS: EPS is a rare but serious complication of long-term PD. It has a high mortality and morbidity rate. Long-term PD is the most significant factor for triggering EPS. Nutritional support and surgical intervention is the next step if medical treatment fails. Resistant cases should be treated surgically without much delay before the condition deteriorates.
\end{abstract}

CONCLUSION: It can be especially devastating for patients with a long-term PD history to have EPS after a successful transplant. Because EPS is a challenging condition, its management should be done in experienced clinics to decrease its mortality and morbidity rates.

Keywords: Encapsulating peritoneal sclerosis; kidney transplantation; peritoneal dialysis.

\section{INTRODUCTION}

Encapsulating peritoneal sclerosis (EPS) was first described back in 1980 by Gandhi et al. It is a disease related to peritoneal dialysis (PD) with a vague etiology and high mortality. EPS occurs in a minority of patients undergoing chronic PD, but it may be life-threatening. The major risk factor for EPS is the PD duration. A history of abdominal surgery and recurrent peritonitis are other important factors for the development of EPS. ${ }^{[1,2]}$ EPS usually presents with mechanical intestinal obstruction, causing nausea, vomiting, and weight loss. ${ }^{[3-5]}$ EPS occurs after kidney transplantation. ${ }^{[6,7]}$ Immunosuppressive medications and tamoxifen (anti-fibrotic) are used for medical treatment. If medications fail to improve the patient's condition, surgery seems to be the best option. Surgical intervention is usually required in refractory cases, and these patients are associated with high mortality rates. ${ }^{[8,9]}$
In this study, we report our surgical experience in kidney transplant recipients with EPS despite the treatment with tamoxifen and immunosuppression.

\section{MATERIALS AND METHODS}

All patients, 18 years of age and older, who underwent kidney transplantation and had previously received PD were included into this study. Patients who underwent both PD and hemodialysis before the transplantation were excluded. Demographic and clinical data were obtained from the medical documents. The age at the start of PD, gender, the cause of end-stage kidney disease, prior kidney replacement therapy, comorbid disease(s), history of abdominal surgery, PD duration, the number of peritonitis indications for surgery, results of surgery, postoperative complications, and long-term results were evaluated. The EPS diagnosis was made according to the criteria published by the International Society for PD in 2000.

Cite this article as: Bayraktar A, Gök AFK, Emiroğlu S, Bakkaloğlu H. Surgical treatment of post-transplant encapsulating peritoneal sclerosis: A single-center experience. Ulus Travma Acil Cerrahi Derg 2019;25:142-146.

Address for correspondence: Adem Bayraktar, M.D.

İstanbul Üniversitesi İstanbul Tıp Fakültesi, Genel Cerrahi Anabilim Dalı, İstanbul, Turkey

Tel: +90 212 - 631 1366 E-mail: dradem6I@gmail.com

Ulus Travma Acil Cerrahi Derg 2019;25(2):142-146 DOI: 10.5505/tjtes.2018.04838 Submitted: 22.02.2019 Accepted: 25.02.2019 Online: 14.03.2019

Copyright 2019 Turkish Association of Trauma and Emergency Surgery 
Table I. Peritoneal dialysis characteristic and outcomes

\begin{tabular}{lcccc}
\hline $\begin{array}{l}\text { Patient } \\
\text { number } \\
\text { (n) }\end{array}$ & $\begin{array}{c}\text { Duration of } \\
\text { peritoneal dialysis } \\
\text { (months) }\end{array}$ & $\begin{array}{c}\text { Number of } \\
\text { peritonitis } \\
\text { (n) }\end{array}$ & $\begin{array}{c}\text { Dialysate } \\
\text { icodextrin }\end{array}$ & $\begin{array}{c}\text { Surgical intervention } \\
\text { Patient I }\end{array}$ \\
\hline 96 & 2 & Yes & Yes & $\begin{array}{c}\text { Total small intestine enterolysis, partial } \\
\text { peritoneal biopsy }\end{array}$ \\
Patient 2 & 156 & 5 & Small bowel resection, and end ileostomy & Exitus \\
Patient 3 & 108 & 4 & Yes & Enterolysis, partial small bowel resection, \\
Patient 4 & 144 & 4 & Yes & $\begin{array}{c}\text { Total small intestine enterolysis, partial small } \\
\text { bowel resection, and end ileostomy }\end{array}$ \\
\hline
\end{tabular}

\section{RESULTS}

We retrospectively analyzed information on 169 adult patients who underwent kidney transplantation at our center between January 2008 and January 2018-1 I9 patients from a cadaveric and 50 patients from a living donor. Twenty-one patients had received previously PD before the transplantation. The mean PD time was 6.9 (3-14) years. Four patients received surgical treatment for EPS, which occurred after the transplantation. Two of them were males, and the mean age was $4 \mathrm{I}$.

One patient received a cadaveric kidney transplant, and 3 received it from a living donor. All the grafts functioned well in the early period, and there were no complications during the hospitalization. PD characteristic and outcomes of the patients are shown in Table I. All of the patients' PD catheters were removed at kidney transplantation. After the removal of the PD catheter, 3 patients were readmitted within I year, and the remaining patient within 2 years, due to nausea, vomiting, early satiety, and weight loss. In one case, laparotomy, enteroclysis, segmental small intestine resection, and double barrel ileostomy were performed due to empty organ perfo-
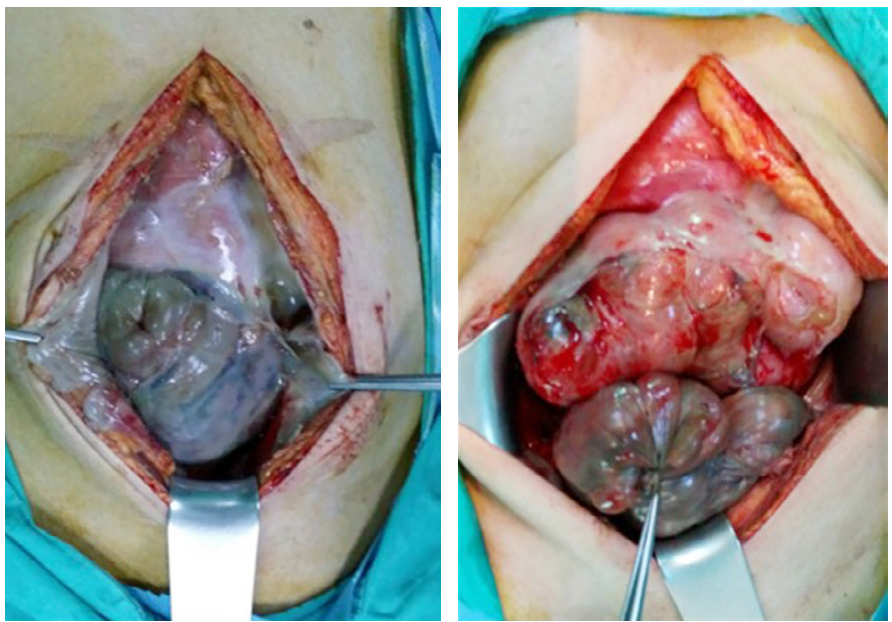
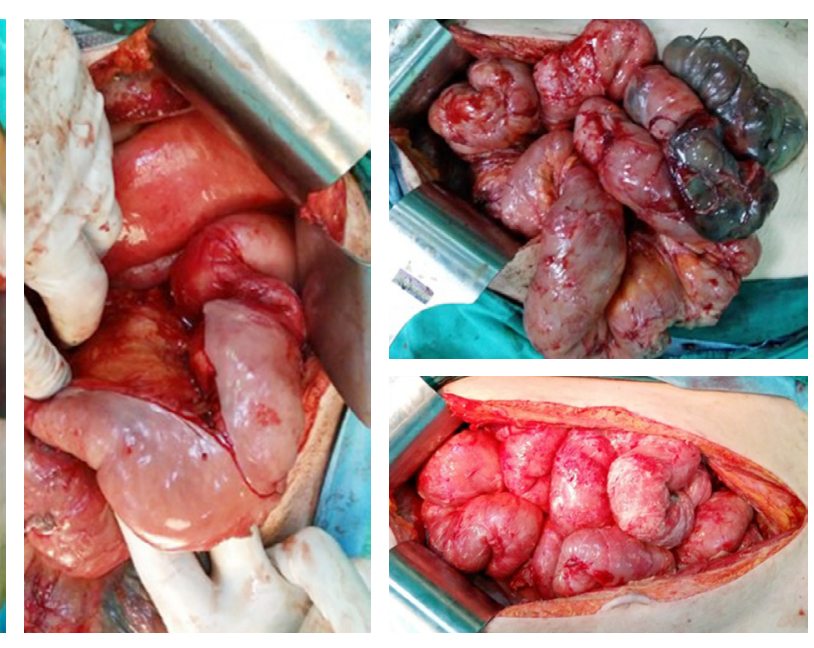

ration (Figs. I and 2). We performed diagnostic laparoscopy in I patient with intraperitoneal liquid sampling and peritoneal biopsy (Fig. 3). In 2 cases, laparotomy, total small intestine enterocytes, segmental small intestinal resection, and end ileostomy were performed due to full obstruction of a small intestinal segment. Two patients died because of sepsis. Two patients were discharged without complications, but I had late-term EPS recurrence (Fig. 4).

\section{DISCUSSION}

EPS is a rare but serious complication encountered in patients treated with PD for a long time. Although its prevalence is variable, in Japan, where nearly all patients are managed with PD, the prevalence of EPS is reported to be $2.5 \%$. [10] The prevalence of EPS is $0.9 \%$ in patients who have been on PD less than 5 years, but it is $11.5 \%$ in patients on PD for more than 10 years. ${ }^{[10]}$ According to the Pan-Thames EPS study done in the United Kingdom, 7I\% of III patients diagnosed with EPS have been on PD for more than 5 years. ${ }^{[6]}$ In our study, the mean time of PD duration before the EPS diagnosis is $10.5(9-13)$ years.

Figure 1. Surgery photos of the case with hollow organ perforation. 


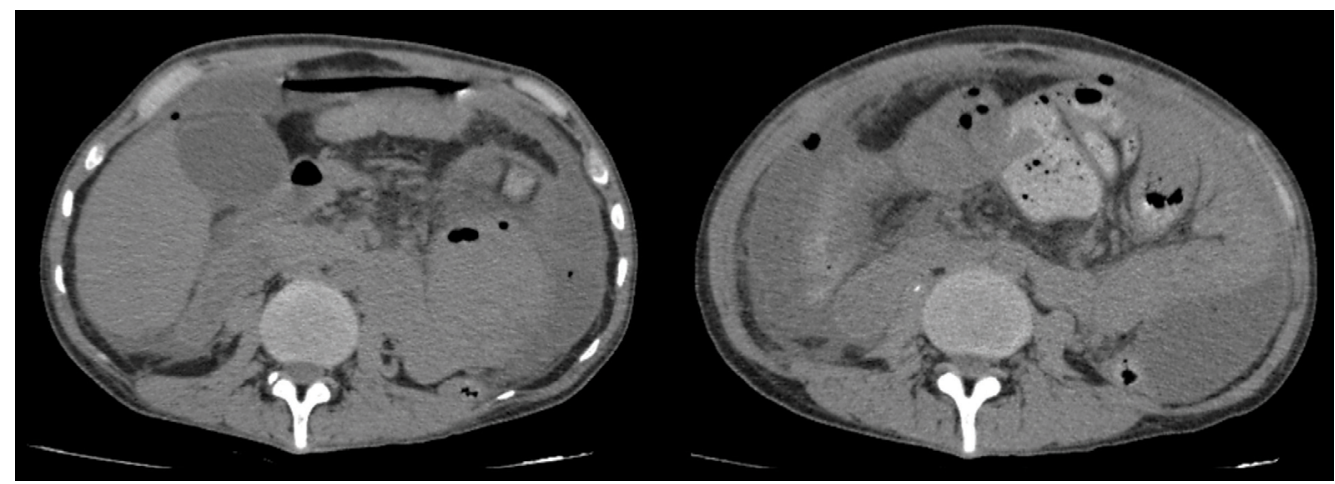

Figure 2. Free air detected in the computed tomography scan of the patient with hollow organ perforation.
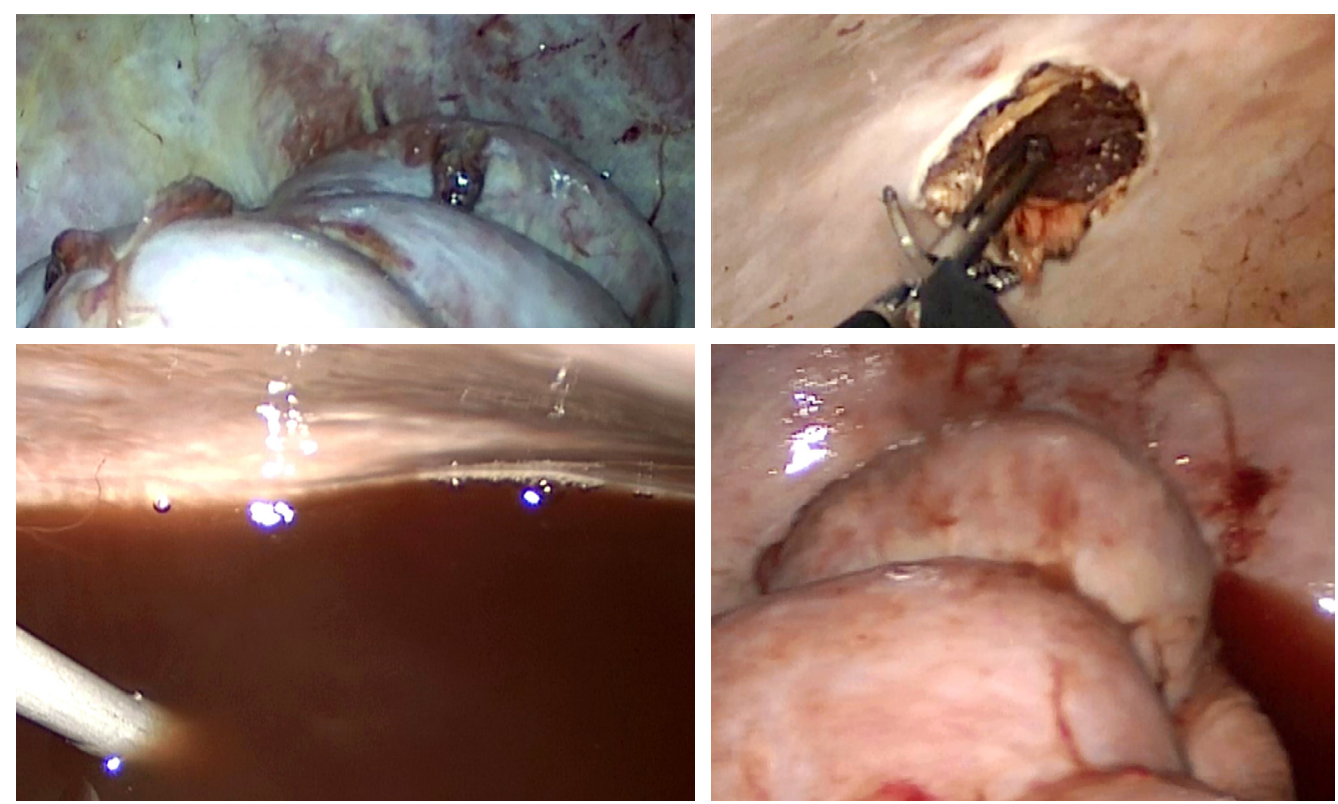

Figure 3. Intraoperative photographs of the patient who underwent a laparoscopic exploration and peritoneal biopsy.

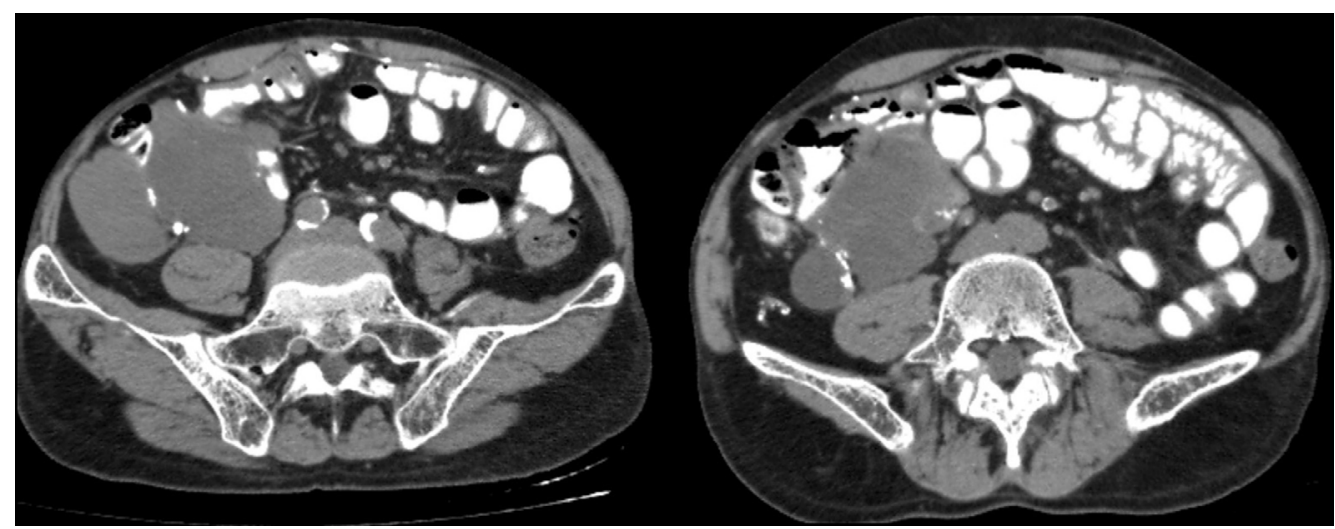

Figure 4. Computed tomography scannings of the case that relapsed after the operation.

The changes in the peritoneal layers and "the second hit" are considered to lead to the clinical findings of EPS. ${ }^{[9]}$ A long-term PD causes an increase in the mesothelial cell count due to a continuous contact with dialysate, a decrease in microvilli, and disorganized distribution of collagen bundles. ${ }^{\left[{ }^{[I]}\right.}$ The mesothelial basement membrane, peritoneal interstitial area, and capil- lary basement membrane are all thickened. ${ }^{[I]}$ In our study, we saw an abundance of blood elements, mesothelial cells, and wide fibrosis in the pathologic specimens. This sclerosis and fibrosis cause a peritonitis attack leading to a second hit, and after the removal of the PD catheter, encapsulation occurs. [9] In our cases, EPS occurred at the latest 2 years after the 
removal of the PD catheter. Because of this, the PD catheter removal after the transplant is blamed for the second hit.

The EPS diagnosis is made according to the criteria published by the International Society for Peritoneal Dialysis in 2000. ${ }^{[2]}$ The EPS diagnosis is based on clinical findings of a systemic inflammatory reaction because an obstructive ileus state must be detected, and thickening of the peritoneum, encapsulation, calcification, and obstruction should be seen on abdominal computed tomography (CT). According to recent studies, abdominal CT is the main imaging modality, and it was also the main diagnostic tool in our studies. The intra-abdominal localized liquid collection, thickening of the peritoneum, and imaging related to ileus were seen in all our patients; additional peritoneal calcifications were encountered in some.

Nearly all EPS cases occur after the PD treatment ends. ${ }^{[10]}$ In the study published in 2009, Brown et al. presented a large series of the EPS cases. Between 2000 and 2007, a total of 1238 patients were treated with PD, and 46 (3.7\%) of them were diagnosed with EPS. Twelve patients were diagnosed while on PD, 29 patients were diagnosed after ending PD, and I patient I year after the treatment had ended. In our study, 3 patients were diagnosed with EPS in the Ist year and I patient in the $2^{\text {nd }}$ year.

Patients diagnosed with EPS are provided with enteral nutrition support if oral intake is inadequate, and there is a significant weight loss observed. If the patient does not tolerate the enteral support, parenteral nutrition can be considered. Additional anti-inflammatory and anti-fibrotic drugs can be used if necessary. If there is no response to medical therapy, a surgical intervention is the next step. According to a report published in Japan, out of 1958 patients treated with PD, 48 presented with EPS. While $38.5 \%$ of the cases were treated with corticosteroids, $58.3 \%$ were treated surgically. [13] Medical treatment options for EPS are corticosteroids followed by immunosuppressive drugs such as azathioprine, sirolimus, and tacrolimus, and anti-fibrotic drugs such as tamoxifen. The timing of surgical intervention if medical treatment fails is critical. Surgical treatment must be sought before the condition of the patient deteriorates. ${ }^{[9]}$ Laparotomy, total small intestine enteroclysis, segmental small intestinal resection, and end ileostomy due to a full obstruction of a small intestinal segment were performed in 2 cases. One patient died due to sepsis complications in the early postoperative period. In one case, laparotomy, enteroclysis, segmental small intestine resection, and double-barreled ileostomy were performed due to empty organ perforation. The patient did not have any recurrence in the follow-up period. One patient had an incomplete obstruction, so no surgical intervention was required. In I case, we needed to perform diagnostic laparoscopy, intra-abdominal liquid sampling, and peritoneal biopsy. This patient died due to septic complications in the early postoperative period. The mortality rate was $50 \%$ in our small patient sample.

In conclusion, EPS is a rare but serious complication of longterm PD. It has a high mortality and morbidity rate. The ending of PD treatment in long-term dialysis patients after a kidney transplant seems to be the most significant factor triggering EPS. Nutritional support and surgical intervention is the next step if the medical treatment fails. Resistant cases should be treated surgically without much delay before the condition deteriorates. It can be especially devastating for patients with a long-term PD history to have EPS after a successful transplant. Because EPS is a challenging condition, its management should be done in experienced clinics to decrease its mortality and morbidity rates.

Conflict of interest: None declared.

\section{REFERENCES}

1. Celik O, Celik N, Hascalik S, Sahin I, Aydin S, Ozerol E. An appraisal of serum preptin levels in PCOS. Fertil Steril 2011;95:314-6. [CrossRef]

2. Guest $\mathrm{S}$. Hypothesis: gender and encapsulating peritoneal sclerosis. Perit Dial Int 2009;29:489-91.

3. Guest S. Tamoxifen therapy for encapsulating peritoneal sclerosis: mechanism of action and update on clinical experiences. Perit Dial Int 2009;29:252-5.

4. Nakamoto H. Encapsulating peritoneal sclerosis--a clinician's approach to diagnosis and medical treatment. Perit Dial Int 2005;25 Suppl 4:S308.

5. Lo WK, Kawanishi H. Encapsulating peritoneal sclerosis-medical and surgical treatment. Perit Dial Int 2009;29 Suppl 2:S211-4.

6. Balasubramaniam G, Brown EA, Davenport A, Cairns H, Cooper B, Fan SL, et al. The Pan-Thames EPS study: treatment and outcomes of encapsulating peritoneal sclerosis. Nephrol Dial Transplant 2009;24:3209-15.

7. Fieren MW, Betjes MG, Korte MR, Boer WH. Posttransplant encapsulating peritoneal sclerosis: a worrying new trend? Perit Dial Int 2007;27:619-24.

8. Saito A. Peritoneal dialysis in Japan: the issue of encapsulating peritoneal sclerosis and future challenges. Perit Dial Int 2005;25 Suppl 4:S77-82.

9. Augustine T, Brown PW, Davies SD, Summers AM, Wilkie ME. Encapsulating peritoneal sclerosis: clinical significance and implications. Nephron Clin Pract 2009;111:c149-54. [CrossRef]

10. Kawanishi H, Moriishi M. Encapsulating peritoneal sclerosis: prevention and treatment. Perit Dial Int 2007;27 Suppl 2:S289-92.

11. Yllmaz R, Arıc1 M. Long-term Complications of Peritoneal Dialysis. Turk Neph Dial Transpl 2007;16 Suppl 2:62-7.

12. Kawaguchi Y, Kawanishi H, Mujais S, Topley N, Oreopoulos DG. Encapsulating peritoneal sclerosis: definition, etiology, diagnosis, and treatment. International Society for Peritoneal Dialysis Ad Hoc Committee on Ultrafiltration Management in Peritoneal Dialysis. Perit Dial Int 2000;20 Suppl 4:S43-55.

13. Kawanishi H, Kawaguchi Y, Fukui H, Hara S, Imada A, Kubo H, et al. Encapsulating peritoneal sclerosis in Japan: a prospective, controlled, multicenter study. Am J Kidney Dis 2004;44:729-37. [CrossRef] 
ORİJINAL ÇALIŞMA - ÖZET

\section{Böbrek nakli sonrası gelişen enkapsüle periton sklerozunda cerrahi tedavi: Tek merkez deneyimi}

\section{Dr. Adem Bayraktar, Dr. Ali Fuat Kaan Gök, Dr. Selman Emiroğlu, Dr. Hüseyin Bakkaloğlu}

Istanbul Üniversitesi İstanbul Tıp Fakültesi, Genel Cerrahi Anabilim Dalı, İstanbul

AMAÇ: Enkapsüle periton sklerozu (EPS) periton diyalizi (PD) ile ilişkili, etiyolojisi tam bilinmeyen ve yüksek mortaliteye sahip bir hastalıktır. Bu çalışmada amacımız EPS olgularında tedavi seçeneklerini değerlendirmektir.

GEREÇ VE YÖNTEM: Ocak 2008-20I8 tarihleri arasında 169 hastaya böbrek nakli yapıldı. Yüz on dokuzu kadavradan, 50'si canlı donörden nakil yapıldı. Yirmi bir hasta nakil öncesi PD yapmaktaydı. Ortalama PD süresi 6.9 (3-14) yıl idi. Dört hastaya nakil sonrası gelişen EPS nedeni ile cerrahi tedavi uygulandı. Cerrahi tedavi sonrası, iki hasta sepsis nedeni ile kaybedildi. İki hasta komplikasyonsuz taburcu edildi, ancak birinde geç dönem EPS nüksü gelişti.

BULGULAR: Enkapsüle periton sklerozu uzun süreli PD’nin nadir fakat ciddi bir komplikasyonudur. Mortalite ve mortalite oranı yüksektir. Uzun süreli PD, EPS'yi tetiklemede en önemli faktördür. Tıbbi tedavi ve beslenme desteği başarısız olursa, cerrahi müdahale sonraki adımdır. Tıbbi tedaviye dirençli olgularda hastanın genel durumu bozulmadan ve gecikmeden cerrahi tedavi yapılmalıdır.

TARTIŞMA: Uzun süreli PD öyküsü olan hastaların başarılı bir nakil sonrası EPS olması özellikle yıkıcı olabilir. Zor bir durum olarak, mortalite ve morbidite oranlarını azaltmak için EPS yönetimi deneyimli kliniklerde yapılmalıdır.

Anahtar sözcükler: Böbrek nakli; enkapsüle periton sklerozu; periton diyalizi.

Ulus Travma Acil Cerrahi Derg 2019;25(2): I42-146 doi: 10.5505/tjtes.2019.04838 